\title{
Effects of Clinorotation on the Enzyme Activities and Morphology of Zea mays Seedlings
}

\author{
Alexander Oseghale Orukpe ${ }^{1}$, Geofrey Obinna Anoliefo ${ }^{2}$, Beckley Ikhajiagbe ${ }^{2}$ \\ ${ }^{1}$ CAR-NASRDA Space Laboratory, University of Benin, Benin, Nigeria \\ ${ }^{2}$ Plant Biology and Biotechnology Department, University of Benin, Benin, Nigeria \\ Email address: \\ alexanorukpe@gmail.com (A. O. Orukpe), alex.orukpe@carnasrda.com (A. O. Orukpe), obidimbuanoliefo@uniben.edu (G. O. Anoliefo), \\ Beckley.ikhajiagbe@uniben.edu (B. Ikhajiagbe)
}

\section{To cite this article:}

Alexander Oseghale Orukpe, Geofrey Obinna Anoliefo, Beckley Ikhajiagbe. Effects of Clinorotation on the Enzyme Activities and Morphology of Zea mays Seedlings. American Journal of Life Sciences. Vol. 9, No. 1, 2021, pp. 11-18. doi: 10.11648/j.ajls.20210901.13

Received: January 5, 2021; Accepted: January 13, 2021; Published: March 22, 2021

\begin{abstract}
For sustainable space exploration there is need for torrential food supply. Apart from food in storage, constant production is vital as this could also serve as a source of Oxygen when activated during space expedition. However, the impact of gravity in crop development is significant. This study therefore, investigated the morphological and physiological responses of Maize (Zea mays) seedlings subjected to clinorotation. Agar Agar was used as source of nutrient for the developing seedlings. The Agar was prepared by measuring $1-1.5 \mathrm{~g}$ and made up to $100 \mathrm{ml}$ with tap water. Seeds were collected in the seed bank of the Space-Earth Environment Research Laboratory, Benin City. Three sets of petri dishes were prepared and marked; one for normal surface, one rotated at $90^{\circ} \mathrm{C}$ and another set for clinorotation. Those for clinorotation were rotated at three different times; with 1, 2, and $3 \mathrm{rpm}$ for $6 \mathrm{hrs}$ respectively. The plumule, radicle and Enzyme activities were measured and analysed after four days. Results showed significant difference in germination parameters as occasioned by microgravity. Where as clinorotation enhanced radicule length $(1.8-2.1 \mathrm{~cm})$, effect on plumule was minimal $(\mathrm{p}>0.05)$. Significant increase in CAT activity in the plumule was reported $(7.59 \mathrm{~mol} / \mathrm{sec})$ in the clinorotated $(1 \mathrm{rpm})$ seed compared to the control $(2.56 \mathrm{~mol} / \mathrm{sec})$. MDA activity in both radicle and plumule were higher than that of the control $(\mathrm{p}<0.05)$. Microscopic study of the cells was carried out using a binocular microscope (Labo) with a camera and result showed that the normal surface sample cells were arranged concentrically with spaces, while that of clinorotated seeds were arranged concentrically but highly packed with little spaces for the plumule. For the radicle, the normal surface sample cells were scattered within the plant with more spaces, while that of clinorotated were mostly clustered throughout.
\end{abstract}

Keywords: EA: Enzyme Activities, MDA: Malondealdehyde, Clinorotation

\section{Introduction}

Human population growth rate has not been successfully controlled with all forms of family planning. There could be a time when the earth is carrying capacity could be over shot both in terms of space and life sustainability. Space scientists therefore thought it wise to explore other planets for habitation through colonization, mineral exploitation and possible technology testing [70, 72-74].

Space exploration however is limited by a number of limitations especially unsustainable food supply. The production of food to meet the nutritional needs of astronaut is important, this will also enhance $\mathrm{O}_{2}$ supply via plant cultivation [43-44, 46, 57].
The astronauts need to be able to cycle their source of energy for water, oxygen and ready to eat food for example carrot, cucumber, watermelon, maize, cabbage. The most limiting factor in growing these crops in Space is microgravity. The gravitational force in space is almost zero. For plant to grow successfully, they must first germinate and then develop to form seedlings. We are looking at the mechanism of survival of plant in space either on board or the grand [26-27, 48, 51-55].

Reported that when a plant is subjected to clinostat effect, the cells are dispersed compare to the one the earth surface which is concentric in arrangement. For this we believe the 
plant to development this great differences, the plants could either be transformed and use for bioremediation because there are more vacuoles on the planted subjected to clinostat effect, moreso, earlier study shows that the maize that have been subjected to clinostat effect and transferred to the field produced bigger cubs and more seeds. We also believe it help for crop improvement that further help to address Zero hunger as the SDGs two which is now a worldwide pursuit [39-40, 67, 69].

Colonizing Space will depend on the ability to routinely provide for the metabolic needs (oxygen, water, and food) of crew with minimal re-supply from Earth. Throughout history, manned exploration missions have often succeeded or failed according to the degree to which nutrition was considered [6, 28, 31, 62-63].

Gravity is the force of attraction between bodies. It is proportional to the mass of the objects, and inversely proportional to the square root of the distance separating those masses [7-8, 19, 56]. Just as any other planet, Earth has its own gravitational field, which applies a force described as an acceleration of 9.81 meters per second squared (expressed as $1 \mathrm{~g}$ as well) to every object on the surface of the planet. Microgravity is the equivalent of $1 \mu \mathrm{g}$ (1x10-6 g), but the word is used to describe any other acceleration corresponding to gravity below $1 \mathrm{~g}$ on Earth's surface [25, 68].

Many plant space biology experiments have shown abnormalities such as chromosomal breakage failure to produce seed, altered or nonviable embryos, alterations in the cell wall composition and properties, increased breakdown of xyloglucans changes in polar auxin transport, or other morphological abnormalities. Most plant space experiments last less than 18 days. Prior to the present study, plants had only been successfully grown from seed to seed during the course of two experiments, each of which showed developmental alterations $[9,23,32$ 41-42, 60, 66].

Microgravity environment affects plants especially through its physiological activities, the movement of the water and nutrients round the cells lead to high enzyme activities. More so, there is high rate of cell division and also the plants tend to always lengthen [51, 64-65, 75].

Gravity can produce effects related to displacement (motion) and/or deformation. The consequences of having weight are related to internal stress induced over an object manifested as tensile or compressive normal loads [30, 71]. Research about Microgravity effects has improved our knowledge about the importance of gravitational forces on the materials development field, as well as biological field. In order to explore the opportunities of long-term space travel, technologies for growing vegetables and harvest food in space must improve. Understanding how different plants react in a reduced or almost nullified gravity environment can help future development of those technologies [18, 35, $55,58]$. On the other hand, the production of materials could be completely different if the whole process is under the influence of Microgravity forces. Understanding if those differences are beneficial or harmful for the final results is going to be crucial in the development of procedures for material production in space [45, 47, 49-50].

Maize seed was selected because it has short germination period of three to four days and also it is easy to prepare before eating. Catalase and Malondealdehyde enzymes were selected because they are stress enzymes, they help the plant to survive or manage stress.

Some work had been done by some scientists in the simulation of microgravity environment and its effect on plant development $[13,33,50]$. The first successful seed-toseed experiment in microgravity was reported by, who used Arabidopsis thaliana. They observed some viable seeds, but most seeds had nonviable embryos. The second successful experiment was performed with Brassica rapa $[17,34,48$, 59].

To understand the behaviour of plant in space environment, the factor that define the physiological state of plant is the microgravity in space which is different from what is obtainable on earth. This study is to investigate the activities expressed by Catalase and MDA in maize seed subjected to clinorotation as these enzymes helps plants to manage stress.

\section{Materials and Methods}

\subsection{Site Location}

The experiment was carried out at the Space-Earth Environment Research Laboratory, University of Benin operated by Centre for Atmospheric Research of the National Space Research and Development Agency (NASRDA). The study was conducted between November 2018 and May 2019.

\subsection{Preparation of Agar}

The Agar was prepared by weighing $1-1.5 \mathrm{~g}$ in $100 \mathrm{ml}$ of tap water. It was Stirred when boiling for uniform dissolution [68]. After a clear solution was observed, it was allowed to cool for about $5-8$ mins after pouring it on the petri dishes of $30 \mathrm{mls}$ each, sowing followed immediately.

\subsection{Sowing}

Sowing was done after the Agar was observed to be cool by inoculating the petri dishes with maize seeds, 9 seeds per plate. Three petri dishes were inoculated, one for Microgravity experimentation (clinorotation), one for earth gravity experimentation, one extra petri dish in case of any damage to other two petri dishes.

\subsection{Clinorotation}

Three different petri dishes inoculated with an average of seven (7) maize seeds per petri dish, which was then mounted on the clinostat at $1,2,3 \mathrm{rpm}$ respectively with a specific time interval of 6hrs. (2-D, one Dimension clinostat, UN, New York, USA). 


\subsection{Enzyme Analysis}

\subsubsection{Catalase Extraction/Analysis}

One gram of the tissue was excised, $10 \mathrm{ml} \mathrm{PO}_{4}$ buffer pH7.0 was used to grind it and form solution.

Table 1. Catalase extraction and analysis composing the reagents used [24].

\begin{tabular}{llll}
\hline Reagent & Bulk (ml) & Standard (ml) & Test (ml) \\
\hline $0.05 \mathrm{MPO}_{4}$ buffer, pH 7.0 & 0.5 & 1.0 & 0.4 \\
$0.2 \mathrm{MH}_{2} \mathrm{O}_{2}$ & 0.5 & - & 0.5 \\
$5 \mathrm{MH}_{2} \mathrm{SO}_{4}$ & 0.2 & 0.2 & 0.2 \\
$0.01 \mathrm{MKMnO}_{4}$ & 0.5 & 0.5 & 0.5 \\
\hline
\end{tabular}

The solution was properly mixed by inversion and absorbance was taken at 480 nm for $60 \mathrm{Sec}$., the result was recorded. See Table 1 for the composition of the solution.

Enzyme activities was calculated using the formula below:

$$
\text { Catalase Activities }(\text { CatA })=\frac{\Delta \mathrm{Abs} \times \mathrm{V}}{\mathrm{M} \times \operatorname{Vol} . \times \mathrm{W}}
$$

$\boldsymbol{\Delta}$ Abs $=$ Change in absorbance $=$ Standard - Test, $\mathrm{V}=$ Volume of reaction mixture $=1.7 \mathrm{ml}$

$\mathrm{Vol}=$ Volume of aliquot $=0.1 \mathrm{mls}, \mathrm{m}=$ molar extinction of Hydrogen Peroxide $=40 \mathrm{~m}^{-1} \mathrm{~cm}^{-1}, \mathrm{~W}=$ weight of sample in the aliquot

Total Volume of the Crude extract is $2 \mathrm{ml} \mathrm{[15].}$

\subsubsection{Malondialdehyde Extraction/Analysis}

Extraction was done by excising $1 \mathrm{~g}$ of the tissue of the seedling in $10 \mathrm{ml} \mathrm{PO}_{4}$ buffer $\mathrm{pH} 7.0$ and was properly ground and the supernatant collected.

Table 2. Malondialdehyde extraction and analysis, composition of the reagents used.

\begin{tabular}{lll}
\hline Reagent & Bulk $(\mathbf{m l})$ & Test $(\mathbf{m l})$ \\
\hline Water & 0.5 & - \\
TCA-TBA-HCL & 1.0 & 1.0 \\
\hline
\end{tabular}

The mixture was well mixed, boiled for $15 \mathrm{mins}$ in water bath, cooled and centrifuged for $10 \mathrm{mins}$ at $400 \mathrm{rpm}$ and absorbance of $1 \mathrm{ml}$ of the supernatant was taking at $535 \mathrm{~nm}$. (See Table for the composition of the solution). [1]

$$
\text { MDA Activities }=\frac{\mathrm{Abs} \times \mathrm{V}}{\mathrm{M} \times \mathrm{Vol}}
$$

Abs $=$ Absorbance

$\mathrm{V}=$ Volume of reaction mixture $=1.5 \mathrm{ml}$

$\mathrm{M}=$ Molar extinction coefficient $=1.56 \times 10^{5} \mathrm{~cm}$

$\mathrm{Vol}=$ Volume of aliquot $=0.5 \mathrm{ml}$

Volume of crude extract $2 \mathrm{mls}$

\subsection{Cell Examination}

This was done using binocular microscope. A slice of the seedlings was taken and placed on the microscope slide and was viewed at x10 magnification. The photograph was taken through a laptop connected to the microscope [24].

\section{Statistical Analysis, Results and Discussion}

\subsection{Growth Observation}

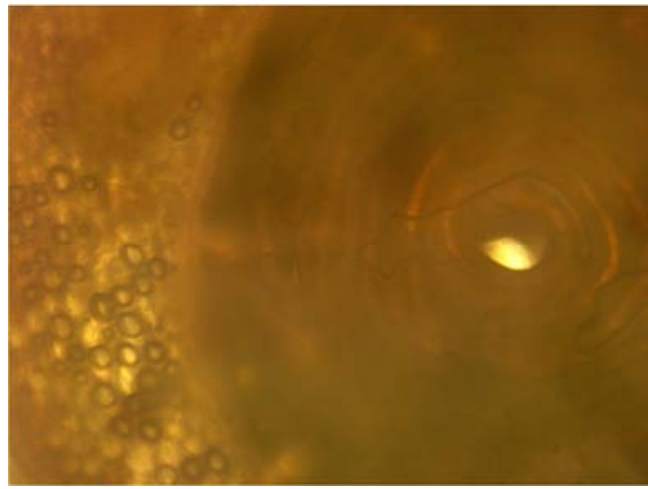

Mag. x10

Figure 1. Cell (Stem) distribution in a plant under gravitational influence.

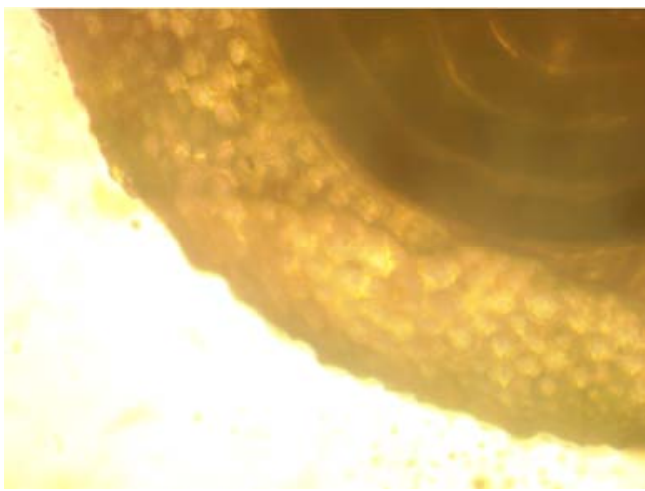

Mag. x10

Figure 2. Cell (Stem) distribution in a plant under microgravity influence.

Figure 1 and Figure 2 show significant difference in their cell arrangement, Figure 1 has cells dispersed or scattered while Figure 4 has it cells packed and arranged in a concentric manner as a result of centrifugal force generated from the rotation of the clinostat. This shows that the cells were affected by the simulated microgravity environment.

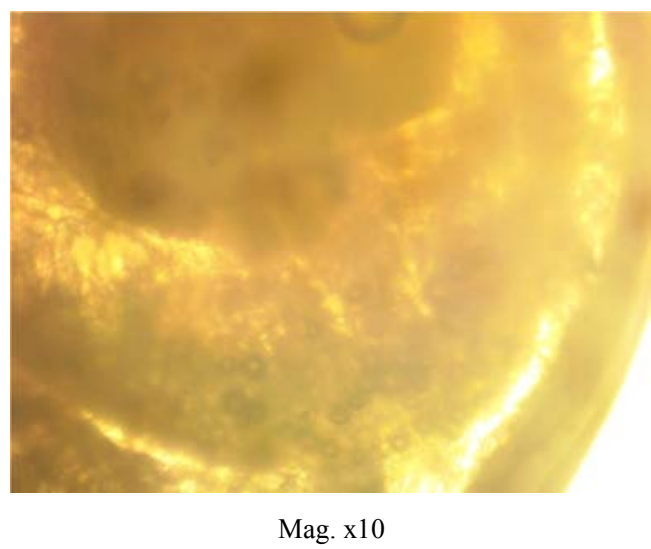

Figure 3. Cell (Root) distribution in a plant under Gravitational influence. 


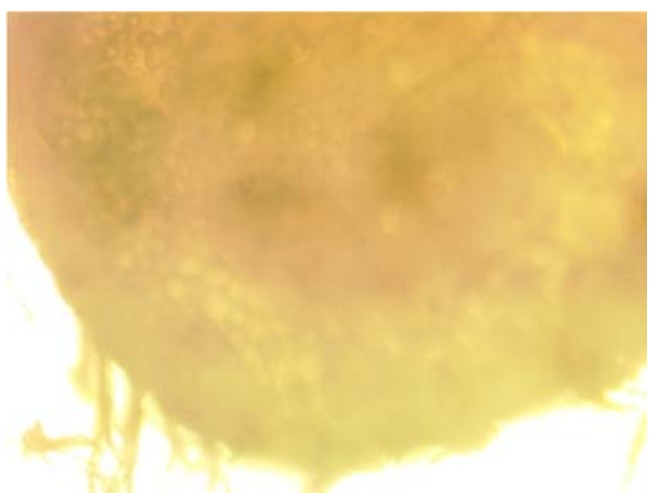

Mag. x10

Figure 4. Cell (Root) distribution in a plant under microgravity influence.

Figures $3 \& 4$ show a significant difference as the cells in Figure 3 were dispersed but not clustered while the cells in Figure 4 were dispersed and clustered.

\subsection{Morphological Examination}

The growth of the root and the plumule were observed and recorded (Table 3 ).

Plumule length of seedlings placed on bench surface and no clinorotation was $1.3 \mathrm{~cm}$. This was not statistically significantly different $(\mathrm{P}>0.05)$ from the seedlings that were exposed to clinorotation

Table 3. Measurements taken between plant under the influence of gravity and microgravity.

\begin{tabular}{lll}
\hline & Plumule length $(\mathbf{c m})$ & Radicle length $(\mathbf{c m})$ \\
\hline Flat surface & $1.3^{\mathrm{a}}$ & $1.5^{\mathrm{a}}$ \\
$90^{\circ}$ turned & $1.6^{\mathrm{a}}$ & $2.1^{\mathrm{a}}$ \\
$3 \mathrm{rpm}$ & $1.8^{\mathrm{a}}$ & $5.6^{\mathrm{b}}$ \\
$2 \mathrm{rpm}$ & $2.1^{\mathrm{a}}$ & $6.3^{\mathrm{b}}$ \\
1 rpm & $1.3^{\mathrm{a}}$ & $4.5^{\mathrm{ab}}$ \\
F statistic & 2.736 & 2.016 \\
p-value & 0.535 & 0.0127 \\
\hline
\end{tabular}

Means on the same column or same row with similar alphabetic superscripts do not differ from one another $(\mathrm{p}>0.05)$.

Figures 5 and 6 show the growth difference between gravity influence and microgravity influence.

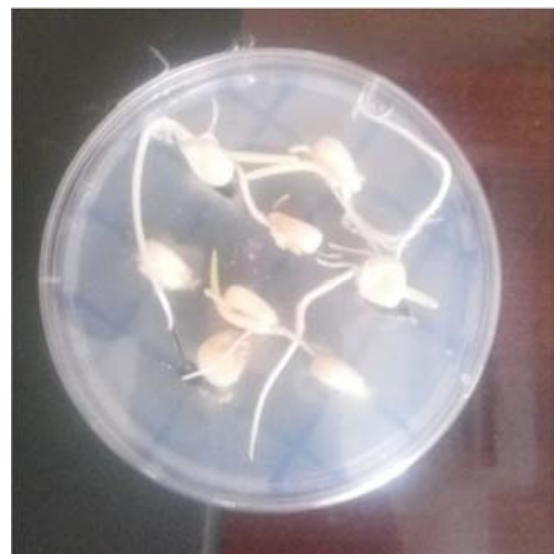

Figure 5. Growth of a clinorotated seedlings of maize.

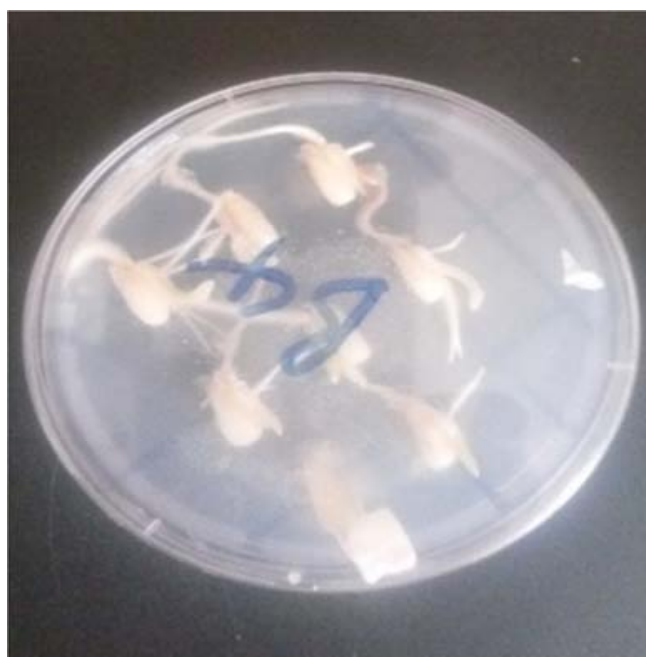

Figure 6. Growth of seedlings of maize under gravity.

The above Figures $5 \& 6$ shows the radicle and the plumule emergence and elongation of seeds. Figure 5 shows the growth of seeds that was clinrorotated and longer in plumule and radicle compare to Figure 6 which is under gravitational force influence within the same period of time.

Catalase activity was higher in the clinorotated plumule than in the radicle as well as in those not clinorotated When seedlings were rotated at $2 \mathrm{rpm}$ for $6 \mathrm{hrs}$, CAT was 7.59 $\mathrm{mol} / \mathrm{sec}$ compared to $2.56 \mathrm{~mol} / \mathrm{sec}$ when placed on a flat surface. However, activities of CAT in the radicle were higher in the unrotated seedlings than when exposed to clinorotation.

Table 4. Catalase responses of the shoot and root of the test plant exposed to clinorotation.

\begin{tabular}{lll}
\hline & \multicolumn{2}{l}{ Catalase activity $(\mathbf{m o l} / \mathbf{s e c})$} \\
\cline { 2 - 3 } & Plumule & Radicle \\
\hline Flat surface & $2.56^{\mathrm{a}}$ & $0.41^{\mathrm{a}}$ \\
$90^{\circ}$ turned & $2.00^{\mathrm{a}}$ & $0.36^{\mathrm{ab}}$ \\
$1 \mathrm{rpm}$ & $7.59^{\mathrm{c}}$ & $0.21^{\mathrm{ab}}$ \\
$2 \mathrm{rpm}$ & $0.91^{\mathrm{b}}$ & $0.08^{\mathrm{a}}$ \\
$3 \mathrm{rpm}$ & $2.65^{\mathrm{a}}$ & $0.08^{\mathrm{a}}$ \\
F statistic & 8.985 & 3.804 \\
p-value & $<0.001$ & 0.018 \\
\hline
\end{tabular}

Means on the same column or same row with similar alphabetic superscripts do not differ from one another $(\mathrm{p}>0.05)$

Table 5. Malondealdehyde responses of the shoots and roots of the test plant exposed to clinorotation.

\begin{tabular}{lll}
\hline & \multicolumn{2}{l}{ Malondealdehyde (mol/sec) } \\
\cline { 2 - 3 } & Plumule & Radicle \\
\hline Flat surface & $2.38^{\mathrm{a}}$ & $1.47^{\mathrm{a}}$ \\
$90^{\circ}$ turned & $6.05^{\mathrm{c}}$ & $4.79^{\mathrm{bc}}$ \\
$1 \mathrm{rpm}$ & $4.79^{\mathrm{b}}$ & $6.44^{\mathrm{b}}$ \\
$2 \mathrm{rpm}$ & $2.81^{\mathrm{a}}$ & $4.19^{\mathrm{ab}}$ \\
$3 \mathrm{rpm}$ & $6.13^{\mathrm{c}}$ & $3.71^{\mathrm{ab}}$ \\
F statistic & 28.764 & 2.004 \\
p-value & $<0.001$ & 0.133 \\
\hline
\end{tabular}

Means on the same column with similar alphabetic superscripts do not differ from one another $(\mathrm{p}>0.05)$

Malondialdehyde responses of the shoot and root of the 
test plants exposed to clinorotation presented in Table 5 . Seedlings on flat surface had an MDA level of $2.38 \mathrm{~mol} / \mathrm{sec}$ in the plumule and $1.47 \mathrm{~mol} / \mathrm{sec}$ in the radicle. Comparatively, seedlings placed at 90 degrees had an MDA of 6.05 units in the plumule and $4.79 \mathrm{~mol} / \mathrm{sec}$ in the radicle. At $3 \mathrm{rpm}$, plumule MDA level of 6.13 units was higher than in the radicle $(3.71 \mathrm{~mol} / \mathrm{sec})$.
Bivariate correlation between, catalase and Malondealdehyde responses of the shoots and roots of the test plant exposed to clinorotation has been presented in Table 6 MDA in the plumule correlated significantly with CAT in the plumule, Similarly, there was significant correlation between CAT in the plumule and CAT in the radicle.

Table 6. Bivariate correlation between, catalase and Malondealdehyde responses of the shoots and roots of the test plant exposed to clinorotation.

\begin{tabular}{llll}
\hline & MDA (plumule) & MDA (radicle) & CAT (plumule) \\
\hline MDA in Plumule & 1 & 0.026 & $-0.454^{*}$ \\
MDA in radicle & 0.026 & 1 & -0.383 \\
CAT in Plumule & $-0.454^{*}$ & -0.383 & 1 \\
CAT in radicle & 0.132 & -0.306 & $0.486^{*}$ \\
\hline
\end{tabular}

*. Correlation is significant at the 0.05 level (2-tailed).

Maize (Zea Mays) seedlings grown for four days on the horizontal 2-D Clinostat at $1 \mathrm{rpm}$ was $4.5 \mathrm{~cm}$ in length for the root while the shoot was $1.3 \mathrm{~cm}$ as against the normal surface data of $1.5 \mathrm{~cm}$ length on the root while $1.3 \mathrm{~cm}$ length on the shoot as indicated in Table 4, this is an indication that microgravity effect alters some activities in the developing state of seedlings. Changes in cell wall properties seem to be well correlated to the growth of each organ in maize seedlings. These results suggest that the growth responses to Micro-g conditions are regulated by both cell-wall mechanical properties and osmotic properties of stem cells, while supporting the hypothesis that under Micro-g in space the cell wall metabolism of seedlings is stimulated, reported in higher plants, leading to an increase in their extensibility [20-22, 59].

Accumulation of water at the tip of the root during clinorotation and also the elongation tendency which leads to tallness of the seedlings under Microgravity showed a high metabolic activity in this study compared to the one under normal surface (earth gravity).

Figures $1 \& 2$ show significant differences in their cell arrangement. Figure 1 has cells dispersed or scattered while Figure 2 had its cells packed and arrange in a concentric manner as a result of centrifugal force generated from the rotation of the clinostat. Furthermore, Figures 3 and 4 show significant differences. As the cells in Figure 4 were dispersed but not clustered, Figure 4 were dispersed and clustered. This is further evidence that main activities occured in the radicle of the plant. Results in root cap of $Z$. mays indicated patterns of differentiation and structure of all cells, as organelle specific, altered under Micro-g conditions. The distribution of amyloplasts (starch granules) happens in the statocytes of roots (columnella cells). Sedimentable amyloplasts are required for the graviperceptive function of columella cells. Differentiation of the putative graviperceptive cells of roots involves changes in relative volumes of amyloplasts [43, 45, 61]. Qualitative observations suggested that amyloplasts in columnella cells were characterized by a "probably low" starch grain (amyloplasts differentiate). Though details remain vague, gravitropism is initiated by sedimentation processes in shoot endoderm and root columnella cells, the sedimentation process itself representing the gravitropic signal. Investigations indicate that Micro-g altered the patterns and magnitude of changes characteristic of cellular differentiation evident in root caps of $Z$. mays [2, 5, 14-15].

Catalase activity was higher in the clinorotated plumule than in the radicle and in those not clinorotated (Table 4). When seedlings were rotated at $2 \mathrm{rpm}$ for $6 \mathrm{hrs}$, CAT was 7.59 units compared to 2.56 units when placed on a flat surface. However, activities of CAT in the radicle were higher in the unrotated seedlings than when exposed to clinorotation. This increase of CAT in plumule against the radicle of clinorotated, could be as a result of the stress created by the rotation of the clinostat for the plant trying to survive in a very different environment compare to the one on normal surface. In chloroplasts of higher plants, for example, interaction of molecular oxygen with electrons carried by different transporters constantly produces ROS, whose levels may grow considerably in stress conditions [1, 3-4, 16].

Malondialdehyde responses of the shoot and root of the test plant exposed to clinorotation shows increase in activities. Seedlings on flat surface had an MDA level of $2.38 \mathrm{~mole} / \mathrm{sec}$ in the plumule and $1.47 \mathrm{~mole} / \mathrm{sec}$ in the radicle. Comparatively, seedlings placed at 90 degrees had an MDA of $6.05 \mathrm{~mole} / \mathrm{sec}$ in the plumule and $4.79 \mathrm{~mole} / \mathrm{sec}$ in the radicle. At $3 \mathrm{rpm}$, plumule MDA level was $6.13 \mathrm{~mole} / \mathrm{sec}$ and was higher than in the radicle $(3.71 \mathrm{~mole} / \mathrm{sec})$. The accumulated ROS can cause DNA damage, lipid peroxidation, and inactivation of certain enzymes. Plant cells respond to ROS by mobilizing the defense systems and enhancing the production of ROS scavenging proteins. In barley leaves grown on board the ISS, the transcription of genes encoding major antioxidant proteins was upregulated. It could also mean that this current study under microgravity could also be upregulated [10-12, 29]. The increase in antioxidant transcript levels was stronger than in plants subjected to salt stress, a well-known inducer of antioxidant biosynthesis. In spaceflight environment, barley leaves accumulated the transcripts of superoxide dismutase, ascorbate peroxidase, glutathione transferase, and catalase. It was previously shown that both ROS production and antioxidant enzyme activity are increased in artificial microgravity conditions in a clinostat $[36-37,71,73-74]$. The probability of oxidative 
stress on board of spaceships has been repeatedly pointed out by many researchers. There was increased transcription of ROS eliminating genes in plant cells, in actual spaceflight environment, which means the increase in any of the part of the plant enzyme activities is as a result of the stress created.

\section{Conclusion}

This study has proven that in microgravity environment, certain characteristics are synonymous with plants in that environment, ranging from observation of water on the root tip, dispersed cells arrangement, relative increase in length and reduction in girth, all these leads to high rate of enzyme activities as was observed on the resulted presented compare to the plant observed under earth gravity. The high expression of the Cat and MDA in microgravity environment confirm that space travel pose different physiological challenges to living system as the system try to adapt to a new environment. The enzymes Cat and MDA are stress dependents which means plants could adjust to the current environment of microgravity with the high production of these stress managing biological molecules, this clearly shows that colonization of other planet using plants for life sustainability is very possible. This is an indication that for a successful colonization of other planets, more attention most be giving to plant biomolecules. There are numerous plants biomolecules that are directly involved in plant physiology, this study open more gateway to study in this respect.

\section{References}

[1] Adam-Vizi, V. and Seregi, A. (1982). Receptor Independent Stimulating Effect of Noradrenaline on $\mathrm{Na}+/ \mathrm{K}+$-ATPase in Rat Brain Homogenate. Role of Lipid Peroxidation. Biochemical Pharmacology, 34, 2231-2236.

[2] Aronne, G., De Micco, V., Ariaudo, P., De Pascale, S., (2003). The effect of uni-axial clinostatrotation on germination and root anatomy of Phaseolus vulgaris L., Plant Biosyst., 137 (2), $155-162$.

[3] Barzegari, A., Saei, A. A., (2012). An Update to Space Biomedical Research: Tissue Engineering in Micro-g Bioreactors, BI, 2 (1), 23-32.

[4] Becker, W., Marxen, J., Epple, M., Reelsen, O., (2000). Influence of Micro-g on crystal formation in biomineralization, J. Appl. Physiol., 89, 1601-1607.

[5] Boonsirichai, K., Guan, C., Chen, R., Masson, P. H., 2002, Root gravitropism: An experimental tool to investigate basic cellular and molecular processes underlying mechanosensing and signal transmission in plants, Annu. Rev. Plant Biol., 53, 421-447.

[6] Bown, S. R, (2003) Scurvy. St. Martin's Press, New York, USA.

[7] Briegleb, W. (1992). Some qualitative and quantitative aspects of the fast-rotating clinostat as a research tool. ASGSB Bulletin, $5(2), 23-30$.

[8] Brungs, S., Hauslage, J., Hilbig, R., Hemmersbach, R., Anken,
R., (2011). Effects of simulated weightlessness on fish otolith growth Clinostat versus Rotating-Wall Vessel, Adv. Space Res., 48, 792-798.

[9] Campbell W. F., Salisbury F. B., Bugbee B., Klassen S., Naegle E., Strickland D. T., Bingham G. E., Levinskikh M., Iljina G. M., Veselova T. D., Sytchev V. N., Podolsky G., McManus W. R., Bubenheim D. L., Stieber J., and Jahns G. (2001) Comparative floral development of Mir-grown and ethylene-treated, Earth-grown Super Dwarf wheat. J Plant Physiol 158: 1051-1060.

[10] Clément, G., Rahm, P., Borasi, G., Slenzka, K., Ed 1. (2006). Fundamentals of Space Biology: Research on Cells, Animals, and Plants in Space. Verlag New York: Springer Science \& Business Media. 18: 1-12.

[11] Dedolph R. R. and M. H. Dipert, (1971) "The physical basis of gravity stimulus nullification by clinostat rotation", Plant Physiology. 47 (6) 756-764.

[12] Dedolph, R. R., Dipert, M. H., (2017). The physical basis of gravity stimulus nullification by clinostat rotation. International Journal of Biophysics. 7 (4): 60-68 67.

[13] Dedolph, R. R., Oemick, D. A., Wilson, B. R., Smith, G. R., (1967). Causal basis of gravity stimulus nullification by clinostat rotation, Plant Physiol., 42 (10), 1373-83.

[14] Eiermann, P., Kopp, S., Hauslage, J., Hemmersbach, R., Gerzer, R., Ivanova, K., (2013). Adaptation of a 2-D Clinostat for Simulated Micro-g Experiments with Adherent Cells, Micro-g Sci. Technol., DOI 10.1007/s12217-0139341-1.

[15] Hausmann, N., Fengler, S., Hennig, A., Franz-Wachtel, M., Hampp, R., Neef, M., (2014). Cytosolic calcium, hydrogen peroxide and related gene expression and protein modulation in Arabidopsis thaliana cell cultures respond immediately toaltered gravitation: parabolic flight data. Plant Biol., 16, $120-128$.

[16] Herranz, R., Anken, R., Boonstra, J., Braun, M., Christianen, P. C. M., De Geest, M., Hauslage, J. Hilbig, R., Hill, R. J. A., Lebert, M., Medina, F. J., Vagt, N., Ullrich, O., Van Loon, J., Hemmersbach, R. (2013). Ground-based facilities for simulation of Micro-g: organism-specific recommendations for their use, and recommended terminology, Astrobiology, 13 (1), 1-17.

[17] Hilaire, E., Peterson, B. V., Guikema J. A., Brown, C. S. (1996). Clinorotation Affects Morphology and Ethylene Production in Soybean Seedlings. Plant Cell Physiology. JSPP, USA. 37 (7): 929-934.

[18] Hirai, Y., Natsuisaka, M., Mashiko, T., Kanahara, M., Saito, Y., Yabu, H., Shimomura, M., Tsujii, K., (2014). Effect of Micro-g on the Formation of Honey combpatterned Films by Dissipative Processes, Int. J. Micro-g Sci. Appl., 31, 3-10.

[19] Horneck G. (1992). Radiobiological experiments in space: A review. Int. J. Radiat. Appl. Instrum. 20, 185-205.

[20] Hoson T. (1997) "Evaluation of the three-dimensional clinostat as a simulator of weightlessness", Planta, 203 (1) S187-S197.

[21] Hoson, T., (2006). The mechanism and significance of gravity resistance in plants, J. Gravit. Physiol., 13, 97-100. 
[22] Hoson, T., Kamisaka, S., Masuda, Y., Yamashita, M., Buchen, B., (1997). Evaluation of the three-dimensional clinostat as a simulator of weightlessness, Planta, 203 (1), 187-197.

[23] Hoson, T., Kamisaka, S., Mori, R., Saiki, M., Nakamura, Y., Wakabayashi, K., Kamisaka, S., (2003). Stimulation of Elongation Growth and Cell Wall Loosening in Rice Coleoptiles under Micro-g Conditions in Space, Plant Cell Physiol., 43 (9), 1067-1071.

[24] Ihongbe, G. I. (2011). Basic Biology Techniques. $2^{\text {nd }}$ Ed. Benson Idahosa University, Benin City. 126p.

[25] Ishii, Y., Hoson, T., Kamisaka, S., Miyamoto, K., Ueda, J., Mantani, S., Fujii, S., Masuda, Y., Yamamoto, R. (1996). Plant growth processes in Arabidopsis under microgravity conditions simulated by clinostat. Biol. Sci. Space 10 (1), 3-7.

[26] Johnson S. P. and Tibbitts T. W. (1968) The liminal angle of a plagiogeotropic organ under weightlessness. Bioscience 18: 655-661.

[27] Kittang, J. A-I, Hoson, T., Iversen, T-H., (2015), The Utilization of Plant Facilities on the International Space Station-The Composition, Growth, and Development of Plant Cell Walls under Micro-g Conditions, Plants, 4 (1), 44-62.

[28] Klaus D. (2001) “Clinostats and bioreactors", Gravitational and Space Biology Bulletin. 14 (2) 55-64.

[29] Klaus, D. M., (2005), Clinostats and bioreactors. Gravit. Space Biol. Bull., 14: 55.

[30] Koesnarpadi, S., Santos, J., Siswanta, D., Rusdiars, B., (2015). Synthesis and characterization of Magnetite Nanoparticle Coated Humic Acid $\left(\mathrm{Fe}_{3} \mathrm{O}_{4} / \mathrm{HA}\right)$, Procedia Environ. Sci., 30, 103-108.

[31] Kozeko, L., Kordyum, E. (2006). The stress protein level under clinorotation in context of the seedling developmental program and the stress response. Microgravity Sci. Technol. 18 (3-4), 254-256.

[32] Krikorian A. D. and O'Connor S. A. (1984) Karyological observations. Ann Bot 54: 49-63.

[33] Kuang A., Xiao Y., and Musgrave M. E. (1996) Cytochemical localization of reserves during seed development in Arabidopsis thaliana under spaceflight conditions. Ann Bot 78: 343-351.

[34] Kuang A., Xiao Y., McClure G., and Musgrave M. E. (2000) Influence of microgravity on ultrastructure and storage reserves in seeds of Brassica rapa L. Ann Bot 85: 851-859.

[35] Lappa, M. (2004). Ed. Fluids, Materials \& Microgravity, Numerical Techniques and Insights into the Physics. Elsevier.

[36] Laurinavichius R. S., Yaroshyus A. V., Marchyukaytis A., Shvyaghdene D. V., and Mashinskiy A. L. (1986) Metabolism of pea plants grown under space flight conditions. USSR Space Life Science Digest 4: 23-25.

[37] Li G., Liu Y., Wang G., Song L. (2004). Reactive oxygen species and antioxidant enzymes activity of Anabaena sp. PCC 7120 (Cyanobacterium) under simulated microgravity. Acta Astronautica. 55, 953-957.

[38] Link B. M. and Cosgrove D. J. (2000) Analysis of peg formation in cucumber seedlings grown on clinostats and in a microgravity (space) environment. J Plant Res 112: 507-516.
[39] Luz, G. M., Mano, J. F., (2010). Mineralized structures in nature: Examples and inspirations for the design of new composite materials and biomaterials. Composites Science and Technology. 70: 1777-1788.

[40] Lyon, C. J. (1972). Auxin control for orientation of pea roots grown on a clinostat or exposed to ethylene. Plant Physiol. 50, 417-420.

[41] Mashinsky A., Ivanova I., Derendyaeva T., Nechitailo G., and Salisbury F. (1994) "From seed-to-seed" experiment with wheat plants under space-flight conditions. Adv Space Res 14: $13-19$.

[42] Merkys A. L. and Laurinavicius R. S. (1983) Complete cycle of individual development of Arabidopsis thaliana (L.) Heynh. plants on board the Salyut-7 orbital station. Doklady Akademii Nauk SSSR 271: 509-512.

[43] Mikhaylenko, N. F., Sytnik, S. K., Zolotareva, E. K. (2001). Effects of slow clinorotation on lipid contents and proton permeability of thylakoid membranes of pea chloroplasts. $A d v$. Space Res. 27 (5), 2007-1010.

[44] Moore R., McClelen C. E., Fondren W. M., and Wang C. L. (1987) Influence of microgravity on root-cap regeneration and the structure of columella cells in Zea mays. Am J Bot 74: 218-223.

[45] Moore, R., Fondren, W. M., (1988). A gradient of endogenous calcium forms in mucilage of graviresponding roots of Zea mays. Ann. Bot., 61 (1), 113-116.

[46] Musgrave M. E., Kuang A., and Matthews S. W. (1997) Plant reproduction during spaceflight: importance of the gaseous environment. Planta 203: S177-S184.

[47] Musgrave M. E., Kuang A., Brown C. S., and Mathews S. W. (1998) Changes in Arabidopsis leaf ultrastructure, chlorophyll and carbohydrate content during spaceflight depend on ventilation. Ann Bot 81: 503-512.

[48] Musgrave M. E., Kuang A., Xia Y., Staut S. C., Bingham G. E., Briarty G., Levinskikh M. A., Sychev V. N., and Podolski I. G. (2000) Gravity independence of seed-to-seed cycling in Brassica rapa. Planta 210: 400-406.

[49] Nedukha, O. M., Vasyltov, I. V. (2001). The effects of extended clinorotation on potato minituber formation and structure. Adv. Space Res. 27 (5), 977-981.

[50] Niu, A., Ochiai, M., Haubold, H., Doi, T., (2012). The United Nations Human Space Technology Initiative (HSTI): Science Activities, 63rd International Astronautical Congress, United Nations Office for Outer Space Affairs, United Nations Office at Vienna, Austria. Naples, Italy, IAC-12-A2.5.11.

[51] Paul A.-L., Wheeler R. M., Levine H. G., and Ferl R. J. (2013a) Fundamental plant biology enabled by the space shuttle. Am J Bot 100: 226-234.

[52] Porterfield D. M. (2002) The biophysical limitations in physiological transport and exchange in plants grown in microgravity. J Plant Growth Regul 21: 177-190.

[53] Porterfield D. M., Dreschel T. W., and Musgrave M. E. (2000) A ground-based comparison of nutrient delivery technologies originally developed for growing plants in the spaceflight environment. Horticulture Technology 10: 179-185. 
[54] Qi, K., Mian, L., Yuanzhong, Z., Li, D., Jianfu, Z., Shenhua, Xu., Shangfeng, W., (2014). Advances of Micro-g sciences, Chin. J. Space Sci., 34 (5), 733-739.

[55] Ramonell K. M., Kuang A., Porterfield D. M., Crispi M. L., Xiao Y., McClure G., and Musgrave M. E. (2001) Influence of atmospheric oxygen on leaf structure and starch deposition in Arabidopsis thaliana. Plant Cell Environ 24: 419-428.

[56] Rogers, M. J. B., Vogt, G. L., Wargo, M. J. (1997). Micro-g, A Teacher's Guide with Activities in Science, Mathematics, and Technology, NASA, EG-1997-08-110-HQ. 177 p.

[57] Sager J. C. and Drysdale A. E. (1996) Concepts, components and controls for a CELSS. In Plant Production in Closed Ecosystems: The International Symposium on Plant Production in Closed Ecosystems, edited by Goto E., editor; Kurata K., editor;, Hayashi M., editor;, and Sase S., editor., Kluwer Academic, Dordrecht, the Netherlands, pp 205-223.

[58] Sarkar, D., Nagaya, T., Koga, K., Nomura, Y., Gruener, R., Seo, H. J., (2000). Culture in vector-averaged gravity under clinostat rotation results in apoptosis of osteoblastic ROS 17/2.8 cells || , J. Bone Miner. Res., 15 (3), 489-98.

[59] Shimazu, T., Yuda, T., Miyamoto, K., Yamashita, M., Ueda, J., (2001). Growth and development in higher plants under Simulated Micro-g conditions on a 3-Dimensional clinostat. Adv. Space Rex., 27 (5), 995-1000.

[60] Soga K., Wakabayashi K., Kamisaka S., and Hoson T. (2002) Stimulation of elongation growth and xyloglucan breakdown in Arabidopsis hypocotyls under microgravity conditions in space. Planta 215: 1040-1046.

[61] Spurr A. R. (1969) A low-viscosity epoxy resin embedding medium for electron microscopy. Journal of Ultrastructural Research 26: 31-43.

[62] Stankovic B. (2001) 2001: A plant space odyssey. Trends in Plant Science 6: 591-593.

[63] Strohm, A. K., Barrett-Wilt, G. A., Masson, P. H., (2014). A functional TOC complex contributes to gravity signal transduction in Arabidopsis, Front. Plant Sci.. 5: 148.

[64] Sugimoto, M., Oono, Y., Gusev, O., Matsumoto, T., Yazawa, T., Levinskikh, M. A., Sychev, V. N., Bingham, G. E., Wheeler, R., Hummerick, M., (2014). Genome-wide expression analysis of reactive oxygen species gene network in Mizuna plants grown in long-term spaceflight, BMC Plant Biol. 14: 4.

[65] Ueda J., Miyamoto K., Yuda T., Hoshino T., Sato K., Fujii S., Kamigaichi S., Izumi R., Isioka N., Aizawa S., Yoshizaki I., Shimazu T., and Fukui K. (2000) STS-95 space experiment for plant growth and development, and auxin polar transport. Biological Sciences in Space 14: 47-57.

[66] United Nations Office for Outer Space Affairs (2013). "Human Space Technology Initiative", United Nations Outer Space Office, Vienna, Austria. Pp 62.

[67] United Nations Office for Outer Space Affairs (2013). "Teacher's Guide to Plant Experiments in Microgravity", United Nations Office for Outer Space Affairs, Vienna, Austria. p63: 12.

[68] United Nations Office for Outer Space Affairs (UNOOSA) (2012). "United Nations Programme on Space Applications", United Nations Office, Vienna, Austria. Pp 52.

[69] United Nations, General Assembly, Official Records TwentyThird Session (1968), Agenda item 24. Report of the Committee on the Peaceful Uses of Outer Space, Annex II "Documentation on the United Nations Conference on the Exploration and Peaceful Uses of Outer Space”, New York.

[70] United States of America, National Aeronautics and Space Administration (2010). Reference Guide to the International Space Station. P12.

[71] Van Loon, J. J. (2007) "Some history and use of the Random Positioning Machine, RPM, in gravity related research", Advances in Space Research. 39 (7) 1161-1165.

[72] World Health Organization. (2018). Bulletin. P6

[73] Wolverton C. and Kiss J. (2009) An update on plant space biology. Gravitational Space Biology 22: 13-20.

[74] Yamada, M., Takeuchi, Y., Kasahara, H., Murakami, S., Yamashita, M. (1993). Plant growth under clinostatmicrogravity condition. Biol. Sci. Space 7 (2), 116-119.

[75] Zhou W., Durst S. J., De Mars M., Stankovic B., Link B. M., Tellez G., Meyers R. A., Sandstrom P. W., and Abba J. R. (2002) Performance of the Advanced Astroculture plant growth unit during ISS-6A/7A mission. SAE Technical Paper 2002-01-2280, SAE International, Warrendale, PA. 